\title{
PHOSPHOLIPID FATTY ACID COMPOSITION OF RAT, RABBIT, HUMAN AND DOG PLASMA
}

\section{SIÇAN, TAVŞAN, iNSAN VE KÖPEK PLAZMA FOSFOLIPIDLERINNIN YAĞ ASIDİ KOMPOZISYONU}

\section{Bilgehan DOĞRU PEKINNER}

Ankara University, Faculty of Pharmacy, Department of Biochemistry, 06100, Tandoğan-Ankara, TURKEY.

\begin{abstract}
The purpose of this study was to investigate and compare the fatty acids of plasma phospholipids in rat, rabbit, human and dog. The prominent fatty acids of phospholipids in the species were $\mathrm{Ci}^{\wedge} . \mathrm{o}, \mathrm{C}_{18} \mathrm{o}$, $C / s: i, C i_{8: 2}$ and $C_{20} ; 4$. Fatty acids generally decreased in the following order: SFA (Saturated fatty acids) $>$ MUFA (monounsaturated fatty acid) $>$ PUFA (polyunsaturated fatty acid) with little exceptions. PUFA was higher in PE (phosphatidyl ethanolamine) and PC (phosphatidyl choline) and PUFA $>M U F A$ in rabbit and human plasma, whereas PUFA was higher in PC and PS in dog and in PI, PC and SPH in rat. Cis:i was higher than the other MUFA.. Among PUFA $C_{18: 2}$ was higher and arachidonate $\left(C_{20: 4}\right)$ was lower in rabbit compared to other species. $C_{18: 2}$ was major PUFA and $C_{2} o_{: 4}$ was the second one mainly in PC and PE and followed by PS (phosphatidyl serine), PI (phosphatidyl inositol) and SPH (sphingomyelin) in all of the species. Others $\left(C_{20: 2}, C i_{8: 3}, C_{2} o_{: 3}\right.$ and $\left.C_{20 .} s\right)$ were less than $\% 0.1$ in dog and also present in very small amounts in rat. These PUFA were present in PE and PC in rabbit and as well as in the other phospholipids in human. LCPUFAs (long chain polyunsaturated fatty acids) were not present in dog and rat had small amouts of $\mathrm{C}_{22: 4}$ in $\mathbf{P C}$
\end{abstract}

Key Words: plasma phospholipid fatty acids, species.

\section{ÖZET}

Çalışmanın amacı rat, tavşan, insan ve kopek gibi farklı türlerde plazma fosfolipidlerinin yă̆ asitlerini tayin etmek ve kiyaslamaktır. Türlerin fosfolipid yă̆ asitleri başlıca C/e.o, $C_{18: 0}, C_{I s[\mid}, C_{8: 2}$ ve $(\sim<20-4$ dir.

Fosfolipid yă̆ asidi bir kaç istisna dişında genellikle şu sekilde azalmaktadır: SFA (doymuş yă̆ asidi)>MUFA (tekli doymamış yağ asidi)>PUFA (çoklu doymamıs yă̆ asidi). PUFA PE (fosfatidil etanolamin) ve PC (fosfatidil kolin) de yüksek düzeydedir ve tavşan ve insan plazmasında PUFA yüzdesi MUFA ya göre fazladır. Öte yandan PUFA köpekde PC ve PS(fosfatidil serin) de ve ratda ise PI (fosfatidil inozitol), PC ve SPH (sfmgomiyelin) de yüksek bulunmuştur. $C_{18: l}$ diğer MUFA ye kiyasla fazlaydl. PUFA içinde $C_{8: 2}$ tavşanda diğer türlerle klyaslanıldlğında yüksek ve $C_{20: 4}$ ise düşüktü. $C_{18: 2}$ major PUFA olup $C_{20: 4}$ bunu takip etti. Buyağ asitleri bütün türlerde başlica PC ve PE de ve müteakiben PS, PI ve SPH de konsantre olmustu, Diğer PUFA $\left(C_{i 8: 3}, C_{20.2}, C_{20}-3\right.$ ve $C_{20 .}$ s) köpekde $0.1 \%$ den azdl ve ratda da cok küçük miktarlardaydı. Bu PUFA tavşanda PE ve PC de ve aynı zamanda insanlarda diğer fosfolipidlerde bulundu. Köpekde LCPUFA (uzun zincirli çoklu doymamış yă̆ asitleri) yokdu ve rat PC de $C_{22:} 6$ çok azdl.

Anahtar kelimeler: plazma, fosfolipid, yağ asitleri, türler. 


\section{INTRODUCTION}

Various types of phospholipid classes with different polar head groups are present in mammalian cells and tissues such as phosphatidylethanolamine (PE), phosphatidylcholine (PC), phosphatidylserin (PS) and phosphatidylinositol (PI). Phospholipids have a structural role in red blood cell membrane meanwhile they have a role in phospholipids in plasma. Different types of fatty acids are distributed in various kinds of phospholipids $(1,2)$. The fatty acyl residues of individual phospholipids are under strict metabolic regulation. Fatty acids which are peresent in phospholipids and their long chain polyunsaturated fatty acid derivatives are always being an interest. PUFA are important constituents of all tissues. This is due to the role of PUFA's in regulating the function and the fluidity of cell membranes $(3,4)$ and also as precursors of eicosanoids (5). Furthermore, arachidonic acid itself and some products of its cleavage from membrane phospholipids participate in several intracellular signalling (6).

In studies, the fatty acid pattern of animals has been measured generally in total plasma and total red blood cell membrane phospholipids (7-17), the fatty acids of some special phospholipids have also been reported in species (18-21) and also in human $(22,23)$. However the data related to fatty acids of specific phospholipids in dog is lacking. The fatty acids of different phospholipids can be compared to establish whether particular phospholipids in dog plasma are rich in particular fatty acids. One can also compare the phospholipid fatty acids of different species.

The aim of the study is to assess the fatty acid pattern of plasma phospholipids in dog and compare these with different species such as rat, rabbit and human.

\section{MATERIALS AND METHODS}

\section{Preparation of tissues:}

The blood was drawn from 10 months old male rabbit (n: 3), 6 years old male dog (n: 3), 30 year old male human (n: 3 ) and 3 months old male rat (n: 3). All the species were provided the nutrients and energy for a balanced diet to ensure a healthy and active life.

Blood was collected into a heparinized plastic beaker on ice. Plasma was separated immediately by centrifuging the blood at $1,000 \mathrm{~g}$ for $10 \mathrm{~min}$. 


\section{Lipid extraction and phospholipid fatty acid analysis}

Plasma samples were extracted twice by the method of Verdon and Blumberg's (24) with some modifications.

Plasma was mixed with an equal volume of $0.02 \%$ aqueous SDS (Sigma Ltd.) in a large volumetric tube. Two volumes of $0.002 \%$ BHT (butylated hydroxy toluene) (Sigma Ltd.) in ethanol (BDH chemicals) containing pentamethyl-6-chromanol (oc-tocopherol with no side chain) synthesized (25) was added as an internal standard and mixed. The tubes were kept on ice. 5 volumes of $0.00025 \%$ BHT in $50 \%$ diethylether (May and Baker Ltd.) / hexane (Fisons Ltd.) was added to the mixture and mixed. After centrifugation for $3 \mathrm{~min}$ at $10,000 \mathrm{xg}$, the upper layer was removed and washed with glass-distilled water; dried by passage through a filter containing Na2S04 (Sigma Ltd.) and evaporated to dryness on a rotary evaporator. The lipid was then dissolved in ether/hexane, transferred to a vial and evaporated to dryness under nitrogen. Finally it was dissolved in $50 \%$ ether/hexane and kept in deep freeze until analysis. The extract was analysed by HPLC for the determination of the recovery and for separation of phospholipids. The extraction recovery was $98 \pm 25 \%$ S. D.

\section{Separation of phospholipids by TLC}

Phospholipids were separated on silicagel H (Merck Ltd.) plates of $0.5 \mathrm{~mm}$. The plates were prepared by mixing $40 \mathrm{~g}$ of the silica in $100 \mathrm{ml}$ distilled water. The plates were left to dry in air and were activated in an oven at $120^{\circ} \mathrm{C}$ for an hour. Lipid extracts (up to $2 \mathrm{mg}$ ) and phospholipid standards were applied in a thin line approximately $10 \mathrm{~cm}$ away the origin on $20 \mathrm{x}$ $20 \mathrm{~cm}$ TLC plates as soon as cooling to room temperature. Chloroform (BDH chemicals): methanol (Fisons Ltd.): acetic acid (Sigma Ltd.): water (25: 15: 4: 2 by vol) were used as the developing solvent. The plates were developed for $45 \mathrm{~min}$ in a tank which was lined with filter paper and saturated for an hour. Only the phospholipid standard spots were detected spraying $0.2 \%$ anilinonaphtalene sulphonic acid (Sigma Ltd.) in methanol (HPLC grade) and visualised under a UV lamp and marked. Phospholipids and the markers were then chromatographed and phospholipids were removed and eluted with petroleum ether (Fisons Ltd..): diethyl ether (30 \%) (26). 


\section{Transmethylation and separation of phospholipid fatty acids}

Plasma phospholipids were transmethylated by the method of Christie, (27). To each tube containing silica (Merck Ltd.) with the lipid sample (1-2 mg), 2.5\% H2SO4 (v/v), (2 vol) in anhydrous methanol (Fisons Ltd.) was added and mixed. A known amount of PC with two $\mathrm{C}_{15}$ saturated fatty acids (Sigma Ltd.) were added to the mixture as reference. All sample tubes were then thightly capped and incubated for 2 hours at $70^{\circ} \mathrm{C}$. After adding $5 \mathrm{vol}$ of $5 \% \mathrm{NaCl}$ (Sigma Ltd.) saturated with $\mathrm{NaHC03}$ (Sigma Ltd.), the mixture was extracted 3 times with 3 volumes of petroleum ether. It was evaporated to dryness and dissolved in a small volume of HPLC grade hexane. The standards (meythyl esters of fatty acids) and the methylated sample extracts were then applied to Silicagel 60 GF254 TLC plates (0.5 mm thick). Petroleum ether : diethyl ether : acetic acid (90:10:1 by vol) were used as the developing solvent (28). Short- and longchain methylated fatty acid esters were successfully separated from cholesterol and more polar compounds which remain at or near the origin. They were also separated from hydrocarbons and BHT added as an antioxidant, which migrated ahead. Only the standards were visualised by the dodecamolybdophosphoric acid (Fisons Ltd.) in ethanol sprayed which developed a blue colour by heating. The methyl esters of fatty acids were eluted from the silicagel with petroleum ether / hexane $(50 \%)$ containing $0.01 \%$ BHT. The solvent was then evaporated in a rotary evaporator and dissolved in a small volume of HPLC grade hexane (Fisons Ltd.) and stored at $-40{ }^{\circ} \mathrm{C}$ until analysis.

\section{Estimation of methyl esters of fatty acids by GC}

GC analysis was carried at on a Hewlett Packard GC model 5890 A with an x - meter Carbowax 20 m capillary column. The detector temperature was 230 C. Helium was used as a carrier gas $(50 \mathrm{ml} / \mathrm{min})$. The oven temperature was programmed from $50 \mathrm{C}$ to $230 \mathrm{C}$ at a rate of $12 \mathrm{C} / \mathrm{min}$. Peak areas and retention times were measured with a reporting integrator Hewlett Packard model, SP 4270. Fatty acids were identified by comparing their retention time with those of standard methyl fatty acid esters from Sigma Ltd. PC with two C15 saturated fatty acids that are rarely found in nature was attached to the mixture to be transmethylated for recovery (27). 


\section{Diet of the species}

Standard diet for the dogs:

Dogs were fed pellets (Friskies Go-Dog pellets, Friskies Pet Care, U. K.) containing meat and animal derivatives, cereals, derivatives of vegetable origin, fats and oils, vegetable protein extracts and minerals as ingredients (ash $9 \%$, oil $9 \%$, protein $24 \%$, fibre $5 \%$, , copper 11 $\mathrm{mg} / \mathrm{kg}$, vitamin D $450 \mathrm{iu} / \mathrm{kg}$ vitamin E $60 \mathrm{mg} / \mathrm{kg}$, vitamin A $5400 \mathrm{iu} / \mathrm{kg}$ ) were the diet of the dogs.

Standard diet for the rabbits:

Rabbits were fed with a high fibre diet (Beekay, Bantin and Kingman Ltd, U.K.) with a fixed formula containing ground oats, linseed meal, grass meal, wheatfeed, barley meal, fats and oils, fish meal, minerals, vitamins and trace elements (crude protein $18 \%$, crude oil $4 \%$, crude fibre $9 \%$, nitrogen free extract $50 \%$, ash $7 \%$, dry matter $88 \%$ ). Also present were saturated fatty acids $0.75 \%$, unsaturated fatty acids $1.84 \%$ and linoleic acid as $1.24 \%$. Added vitamins were vitamin A $36000 \mathrm{iu} / \mathrm{kg}$, vitamin D3 $2000 \mathrm{iu} / \mathrm{kg}$, vitamin E $130 \mathrm{mg} / \mathrm{kg}$.

Humans had a healthy balanced diet.

Diet for the rats:

Rats had a low protein, high quality diet (Rat and Mouse No. 1 Modified, SDS Ltd., Witham, Essex) designed to maintain rats in good health over long periods. The pellets given to rats were made up of crude fibre $4.3 \%$, ash $5.8 \%$, crude protein $14.6 \%$, crude oil $2.6 \%$, and nitrogen free extract $62.7 \%$. (Fatty acids were palmitoleic acid $\left(\mathrm{C}_{16: 1}\right) \quad 0.07 \%$, oleic acid $\left(\mathrm{C}_{18: 1}\right) 0.74 \%$, linoleic acid $\left(\mathrm{C}_{18: 2}\right) 0.56 \%$, linolenic acid $\left(\mathrm{C}_{18: 3}\right) 0.05 \%$, arachidonic acid $\left(\mathrm{C}_{20: 4}\right) \quad 0.13 \%$, palmitic acid $\left(\mathrm{C}_{16: 0}\right) 0.31 \%$ and stearic acid $\left.\left(\mathrm{C}_{18: 0}\right) 0.04 \%\right)$. Retinol 1922 ug/kg (1 ug retinol : 3.3 IU vitamin A activity), a-tocopherol $68.3 \mathrm{mg} / \mathrm{kg}$, cholecalciferol 15.1 ug/kg (1 ug cholecalciferol : 40 IU vitamin D3 activity) were added to the pellets.

\section{RESULTS AND DISCUSSION}

Rabbit

SFAs (Ci6: 0, $\mathrm{C}_{\text {]8: }} \mathrm{O}, \mathrm{C}_{2} \mathrm{0}: \mathrm{o}$ ) were present in all of the phospholipids whereas $\mathrm{C}_{2} 2 \mathrm{o}$ was present in PS and $\mathrm{C}_{23: 0}$ in PE and PC (Table 1). Among MUFA the amount of $\mathrm{Ci}_{8: 1}$ was found to be higher than that of $\mathrm{Ci}_{6}: \mathrm{i}$ in all of the plasma phospholipids, percentages ranged between 9- 
$14 \%$ and $1-9 \%$, respectively. $\mathrm{C}_{2} 2: \mathrm{i}$ was less than $0.1 \%$. Some of PUFA were higher than MUFA. C $\mathrm{g} 2$ was highest in PC (37\%) and PE (24\%) than the other phospholipids, C20:4 was highest in PE (9.7\%) and PI (6.7\%). $\mathrm{C}_{8: 3}$ and $\mathrm{C}_{20:} 5$ were detected only in PE and PC in small amounts $(0.2-1 \%)$. Among PUFA $\mathrm{C}_{18: 2}(37-6 \%)$ was highest than the others followed by $\mathrm{C}_{20}: 4(4-10 \%)$.. The LCPUFA $\left(\mathrm{C}_{22}: 4\right.$ and $\left.\mathrm{C}_{22:} 6\right)$ were less than $0.1 \%$ and $\mathrm{C}_{22}: 6$ was $0.2 \%$ in PE.

Dog

$\mathrm{C}_{16: 0}, \mathrm{C}_{18: 0}, \mathrm{C}_{8:} 1, \mathrm{C}_{18:} 2$ and $\mathrm{C}_{20: 0}$ fatty acids were found in high amounts in ali of the phospholipids detected (Table 4). $\mathrm{Cl}_{8:} 3$ was not present. Only $\mathrm{Cl}_{6:} 1$ and $\mathrm{Cl}_{8:} 1$ of MUFA were detected in the phospholipids of dog. Ciöa was (8\%) was present in LPC, (7 \%) in SPH and (2$5 \%$ ) in the other phospholipids. $\mathrm{C}_{18: 1}$ was found to be higher when compared to Ci6:i .Cis:3 was not present. Only $\mathrm{C}_{16: 1}$ and $\mathrm{C}_{18-1}$ were detected in phospholipids of dog. C1e in the phospholipids, being $13 \%$ in PE and $\mathrm{SPH}, 10-11 \%$ in the others. $\mathrm{C}_{8}: 2$ and $\mathrm{C}_{2} \mathrm{o}: 4$ were found as PUFA's. There were no LCPUFA. Önce again Ci8:2 was higher than $\mathrm{C}_{2} 0: 4$ among PUFA. Ci8:2 was found as $16 \%$ in PE, $14 \%$ in PS and 8-11\% in the other phospholipids. $\mathrm{C}_{20:} 4$ was the highest in PC and PS (12\% and $7 \%$, respectively) and also was detected as $4 \%$ in LPC. it was not present in SPH and PE.

Human

Ci6:i, $\mathrm{Cl}_{6}: \mathrm{O}, \mathrm{C}_{18: 0}, \mathrm{C}_{18:}, \mathrm{Cl}_{8: 2}, \mathrm{Cl}_{8:} 3, \mathrm{C}_{20 ;} 4$ and $\mathrm{C} 20.5$ were the prominent fatty acids in human plasma phospholipids (Table 3). SFAs Ci6:o and $\mathrm{Cl}_{8:}$ o were higher than $\mathrm{C}_{2}$ o.o- Among MUFA Ciöi and $\mathrm{Cl}_{\mathrm{S}: 1}$ were present in ali of the phospholipids vvhereas $\mathrm{C}_{2} \mathrm{O}_{;}$was only present in PS and PI. The percentage of $\mathrm{Cl}_{6: 1}$ was 1-7 vvhereas $12-23 \%$ of $\mathrm{Cls}^{-1 .} \mathrm{Cj}_{8:}$ was significantly higher in ali of the phospholipids being highest in PS, PE and LPC. Among PUFA $\mathrm{C}_{8:} 2$ was the highest one present in ali of the plasma phospholipids $(11-28 \%)$. C20:4 and C20.5 were found to be higher in some of the phospholipids when compared to the other PUFA's (C1s:3 and C22:6)LCPUFA $\left(\mathrm{C}_{22: 6}\right)$ was found in SPH and PC in very low amounts. $\mathrm{C}_{2} 2: \mathrm{i}$ was less than $0.1 \%$.

Rat

$\mathrm{C}_{16: 0}, \mathrm{C}_{18: 0}, \mathrm{C}_{18: 1}, \mathrm{C}_{18 ; 2}, \mathrm{C}_{18: 3}, \mathrm{C}_{20: 0}$ and $\mathrm{C}_{2} 0: 4$ were the main fatty acids of rat plasma phospholipids (Table 4). The percentage of SFA were found to be increased in the follovving order : $\mathrm{C}_{22: 0}<\mathrm{C} 20.0<\mathrm{C}_{18: 0}<\mathrm{C}_{16: 0}, 2-3 \%, 2-21 \%, 10-20 \%$ and $20-34 \%$, respectively. The percentage of $\mathrm{Cl}_{6}: 1$ ranged between $2-13$ being highest in PS and lovvest in PC, vvhereas Çişi ranged between $6-10$ being highest in PI and PS. Of the MUFA's $\mathrm{C}_{20} 1$ was only present 
in PI and PC $(0.7 \%) . C i_{S: 2}$ was the major PUFA in plasma phospholipids, being highest in PC (28\%) and SPH (25\%) and $12-15 \%$ in the others. The percentage of $\mathrm{C}_{8: 3}$ was $0.5-1.7 \%$ being highest in PI. One of the other main PUFA's was C20.4 - It was found to be higher in PC $(14 \%), 1-4 \%$ in the other phospholipids and not present in SPH. C22.6 was only present in PC $(0.7 \%)$.

Table 1. Fatty acid composition of phospholipids of rabbit plasma

Phospholipids

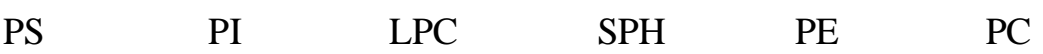

Fatty acids

$\begin{array}{lllllll}\mathrm{C}_{16: 0} & 23.4 \pm 0.5 & 14.9 \pm 0.9 & 30.9 \pm 0.5 & 29.0 \pm 1.9 & 15.6 \pm 0.4 & 18.2 \pm 0.4 \\ \mathrm{C}_{16: 1} & 8.2 \pm 0.2 & 7.05 \pm 1.0 & 7.9 \pm 2.0 & 9.6 \pm 1.6 & 2.4 \pm 0.5 & 0.60 \pm 0.3 \\ \mathrm{C}_{18: 0} & 20.3 \pm 1.6 & 19.2 \pm 4.9 & 18.5 \pm 1.0 & 20.5 \pm 1.4 & 27.9 \pm 3.0 & 23.5 \pm 0.4 \\ \mathrm{C}_{18: 1} & 13.4 \pm 0.8 & 13.7 \pm 1.9 & 14.3 \pm 3.2 & 8.27 \pm 1.1 & 12.1 \pm 0.2 & 9.03 \pm 0.5 \\ \mathrm{C}_{18: 2} & 6.6 \pm 0.5 & 17.6 \pm 2.8 & 5.9 \pm 0.2 & 8.5 \pm 0.9 & 24.1 \pm 0.8 & 37.0 \pm 0.1 \\ \mathrm{C}_{18: 3} & \text { N.D. } & \text { N.D. } & \text { N.D. } & \text { N.D. } & 1.2+0.2 & 0.7 \pm 0.1 \\ \mathrm{C}_{20: 0} & 9.6 \pm 0.4 & 9.0 \pm 1.3 & 7.8 \pm 1.2 & 11.7 \pm 1.0 & 1.4 \pm 0.4 & 0.3 \pm 0.1 \\ \mathrm{C}_{20: 1} & <0.1 & \text { N.D. } & <10.1 & <0.1 & \text { N.D. } & <0.1 \\ \mathrm{C}_{20: 2} & \text { N.D. } & <0.1 & \text { N.D. } & \text { N.D. } & <0.1 & 1.2 \pm 0.3 \\ \mathrm{C}_{20: 3} & <0.1 & <0.1 & \text { N.D. } & <0.1 & 0.30 \pm 0.1 & 1.2 \pm 0.2 \\ \mathrm{C}_{20: 4} & 3.6 \pm 2.0 & 6.7 \pm 1.9 & <0.1 & <0.1 & 9.7 \pm 0.5 & 4.0 \pm 0.1 \\ \mathrm{C}_{20: 5} & \text { N.D. } & \text { N.D. } & \text { N.D. } & \text { N.D. } & 0.7 \pm 0.1 & 0.2 \pm 0.1 \\ \mathrm{C}_{22: 0} & 0.4 \pm 0.2 & <0.1 & <0.1 & <0.1 & \text { N.D. } & <0.1 \\ \mathrm{C}_{22: 1} & <0.1 & <0.1 & <0.1 & <0.1 & \text { N.D. } & \text { N.D. } \\ \mathrm{C}_{22: 4} & \text { N.D. } & <0.1 & \text { N.D. } & <0.1 & \text { N.D. } & \text { N.D. } \\ \mathrm{C}_{22: 6} & \text { N. D. } & \text { N.D. } & <0.1 & <0.1 & \mathbf{0 . 8} \pm 0.1 & \mathbf{0 . 2} \pm \mathbf{0 . 1} \\ \mathrm{C}_{23: 0} & \text { N.D. } & \text { N.D. } & \text { N.D. } & \text { N.D. } & <0.1 & \text { N.D. } \\ \mathrm{C}_{24: 0} & \text { <.1 } & <0.1 & \text { N.D. } & <0.1 & 0.2 \pm 0.1 & \text { N.D. }\end{array}$

Values are percentages of total.

N.D.: Not detected.

Each value represents the mean \pm S.E.M. of three individuals. 
Table 2. Fatty acid composition of phospholipids of rat plasma

Phospholipids

$\begin{array}{lllll}\text { PS } & \text { PI } & \text { LPC } & \text { SPH } & \text { PC }\end{array}$

Fatty acids

\begin{tabular}{|c|c|c|c|c|c|}
\hline $\mathrm{Cl} 6: 0$ & $20.4 \pm \quad 4.5$ & $24.1 \pm 4.9$ & $33.7 \pm 4.6$ & $20.0 \pm 0.7$ & $21 . .3 \pm 0.3$ \\
\hline C16:1 & $12.5 \pm 1.1$ & $6.4+0.7$ & $7.9 \pm 4.4$ & $4.8 \pm 0.9$ & $2.1 \pm 1.0$ \\
\hline $\mathrm{C} 18: 0$ & $9.6 \pm 1.6$ & $18.3 \pm 3.3$ & $11.5 \pm 2.8$ & $19.9 \pm 2.6$ & $14.4 \pm 0.4$ \\
\hline C18:1 & $8.3 \pm 0.6$ & $9.8 \pm 3.8$ & $8.0+1.0-$ & $7.8 \pm 3.4$ & $6.28 \pm 1.0$ \\
\hline $\mathrm{Cl} 18: 2$ & $14.6 \pm 0.2$ & $13.7 \pm 3.1$ & $\mathbf{1 2 . 0}+0.1$ & $25.4 \pm 5.5$ & $28.1 \pm 1.0$ \\
\hline C18:3 & $1.4 \pm 0.8$ & $1.7 \pm 0.7$ & $0.6 \pm 0.1$ & $1.60 \pm 0.5$ & $0.47 \pm 0.2$ \\
\hline $\mathrm{C} 20: 0$ & $21.2+4.8$ & $17.7+5.2$ & $19.2 \pm 4.9$ & $7.9+1.69$ & $2.2 \pm 1.0$ \\
\hline C20:1 & N. D. & $0.7 \pm 0.2$ & $<0.1$ & N. D. & $0.7 \pm 0.2$ \\
\hline $\mathrm{C} 20: 2$ & N. D. & N. D. & $0.3 \pm 0.1$ & N. D. & $<0.1$ \\
\hline $\mathrm{C} 20: 3$ & N. D. & N. D. & N. D. & N. D. & $0.3 \pm 0.1$ \\
\hline C20:4 & $4.4 \pm 0.2$ & $1.2 \pm 0.4$ & $1.5 \pm 0.2$ & N. D. & $14.0 \pm 0.5$ \\
\hline $\mathrm{C} 22: 0$ & $1.9+0.1$ & N. D. & $3.1+0.5$ & N. D. & N. D. \\
\hline C22:4 & N. D. & N. D. & N. D. & N. D. & $0.4 \pm 0.1$ \\
\hline
\end{tabular}

Values are percentages of total.

N.D.: Not detected.

Each value represents the mean \pm S.E.M. of three individuals. 
Table 3. Fatty acid composition of phospholipids of human plasma

\section{Phospholipids}

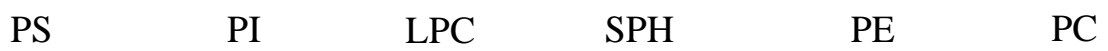

Fatty acids

\begin{tabular}{|c|c|c|c|c|c|c|}
\hline$C_{16: 0}$ & $11.9 \pm 0.8$ & $11.8 \pm 15$ & $18.9 \pm 1.5$ & $16.3 \pm 0.6$ & $13.6 \pm 0.7$ & $25.0 \pm 0.5$ \\
\hline$C_{16: 1}$ & $7.2 \pm 1.7$ & $5.3 \pm 0.3$ & $6.7 \pm 1.7$ & $3.7 \pm 0.8$ & $2.7 \pm 0.8$ & $0.7 \pm 0.3$ \\
\hline $\mathrm{C}_{18: 0}$ & $13.6+2.4$ & $15.7 \pm 18$ & $16.4 \pm 1.3$ & $12.5 \pm 1.7$ & $8.5 \pm 0.5$ & $18.1 \pm 0.6$ \\
\hline $\mathrm{C}_{18: 1}$ & $22.9 \pm 2.1$ & $18.4 \pm 2.4$ & $21.2 \pm 5.8$ & $11.8 \pm 2.0$ & $21.9 \pm 3.9$ & $12.6 \pm 0.4$ \\
\hline$C_{18: 2}$ & $24.4 \pm 4.6$ & $22.2 \pm 1.8$ & $14.5 \pm 0.6$ & $11.0 \pm 3.4$ & $17.8 \pm 1.1$ & $28.0 \pm 1.1$ \\
\hline$C_{18: 3}$ & $2.2 \pm 0.2$ & $9.5 \pm 3.1$ & $0.4 \pm 0.2$ & $1.9 \pm 0.6$ & $0.7 \pm 0.2$ & $0.4 \pm 0.1$ \\
\hline $\mathrm{C}_{20: 0}$ & $6.7 \pm 0.6$ & $7.7 \pm 1.3$ & $6.8 \pm 1.1$ & $4.7 \pm 0.3$ & $2.5 \pm 0.3$ & $0.2 \pm 0.0$ \\
\hline$C_{20: 1}$ & $3.2 \pm 07$ & $5.0 \pm 1.2$ & $<0.1$ & $<0.1$ & N. D. & $0.3 \pm 0.1$ \\
\hline $\mathrm{C}_{20: 3}$ & $<0.1$ & N.D. & $<0.1$ & $<0.1$ & $<0.1$ & $2.8 \pm 0.1$ \\
\hline$C_{20: 4}$ & $<0.1$ & $1.2+0.1$ & $<0.1$ & $1.9 \pm 0.5$ & $14.5 \pm 2.0$ & $5.7 \pm 01$ \\
\hline $\mathrm{C}_{20: 5}$ & 2.9i 1.1 & $2.5 \pm 0.3$ & $9.8 \pm 1.7$ & $3.1 \pm 0.5$ & $4.8 \pm 07$ & $0.8 \pm 0.3$ \\
\hline $\mathrm{C}_{22: 0}$ & $<0.1$ & $<0.1$ & $<0.1$ & $8.90 \pm 2.7$ & $<0.1$ & $<0.1$ \\
\hline $\mathrm{C}_{22: 1}$ & $<0.1$ & N. D. & N.D. & N. D. & $<0.1$ & N.D. \\
\hline $\mathrm{C}_{22: 6}$ & $<0 . !$ & N. D. & $<0.1$ & $1 . .3 \pm 0.2$ & $<0.1$ & $0.2 \pm 0.0$ \\
\hline $\mathrm{C}_{23: 0}$ & $<0.1$ & $<0.1$ & $<0.1$ & $<0.1$ & N.D. & $<0.1$ \\
\hline $\mathrm{C}_{24: 0}$ & $<0.1$ & $<0.1$ & $<0.1$ & $10.2 \pm 15$ & $<0.1$ & $<0.1$ \\
\hline
\end{tabular}

Values are percentages of total.

N.D.: Not detected.

Each legend represents the mean \pm S.E.M. of three individuals. 
Table 4. Fatty acid composition of phospholipids of dog plasma

\section{Phospholipids}

$\begin{array}{lllll}\text { PS } & \text { LPC } & \text { SPH } & \text { PE } & \text { PC }\end{array}$

Fattv acids

$\begin{array}{lllllr}\mathrm{C}_{16: 0} & 22.8 \pm 3.8 & 14.2 \pm 2.0 & 32.5 \pm 12 & 19.8 \pm 3.5 & 17.7 \pm 3.4 \\ \mathrm{C}_{6: 1} & 1.8 \pm 0.8 & 8.4 \pm 19 & 7.05 \pm 1.8 & 4.9 \pm 0.7 & 3.0 \pm 0.54 \\ \mathrm{C}_{18: 0} & 11.1 \pm 0.4 & 9.9 \pm 1.0 & 5.9 \pm 1.1 & 14.5 \pm 0.8 & 18.4 \pm 2.7 \\ \mathrm{C}_{18: 1} & 11.3+05 & 9.9 \pm 1.0 & 13.1 \pm 2.5 & 12.7 \pm 1.0 & 10.9 \pm 0.7 \\ \mathrm{C}_{18: 2} & 14.2 \pm 0.4 & 11.1+0-9 & 8.4 \pm 1.2 & 16.1 \pm 4.0 & 8.5 \pm 2.9 \\ \mathrm{C}_{20: 0} & 10.4 \pm 07 & 6.6 \pm 0.8 & 11.5 \pm 2.4 & 25.7 \pm 1.6 & 14.3 \pm 2.5 \\ \mathrm{C}_{20: 1} & 0.3 \pm 0.1 & 0.2 \pm 0.1 & <0.1 & <0.1 & \text { N. D. } \\ \mathrm{C}_{20: 2} & \text { N. D } & \text { N. D } & \text { N. D. } & <0.1 & \text { N.D. } \\ \mathrm{C}_{20: 3} & \text { N. D. } & \text { N. D. } & <0.1 & <0.1 & \text { N. D. } \\ C_{20: 4} & 6.9 \pm 18 & 3.6 \pm 12 & <0.1 & <0.1 & 11.5 \pm 0.2\end{array}$

Values are percentages of total.

N.D.: Not detected.

Each value represents the mean \pm S.E.M. of three individuals. 
$\mathrm{C}_{16: 0}, \mathrm{C}_{16: 1}, \mathrm{C}_{18: 0} \mathrm{C}_{18: 1}, \mathrm{C}_{18: 2}$ and $C_{2} O-A$ were the prominent fatty acids in plasma phospholipids of rat, rabbit, dog and human. Among the PUFAs, $\mathrm{C}_{20: 5}$ was found only in human plasma whereas long chain PUFA $\mathrm{C}_{2} 2: 6$ was present in some of the phospholipids of the other animals.

C18:2 was the first major PUFA whereas $\mathrm{C}_{20: 4}$ was the second major one in PC and PE. PS, PI and SPH followed them in all of the species. Linoleik asid $\left(\mathrm{Ci}_{8: 2}\right)$ was higher and arachidonate $\left(\mathrm{C}_{2} \mathrm{O}: 4\right)$ was lower in rabbit compared to the other species. This probably indicates the lower activities of elongase and $\mathrm{A}^{5}$-desaturase for the formation of arachidonic acid from linoleic acid in the rabbit. Other PUFA's $\left(\mathrm{C}_{20: 2}, \mathrm{C}_{18: 3}, \mathrm{C}_{20: 3}\right.$ and $\left.\mathrm{C}_{20: 5}\right)$ rather than these two, were less than \% 0.1 in dog and also present in very small amounts in rat. These PUFA's were present in PE and PC phospholipids in rabbit and as well as in the other phospholipids in human. LCPUFAs were not present in dog and rat while it had small amouts of $\mathrm{C}_{22} 4$ in PC. $\mathrm{C}_{22: 6}$ was present in a few phospholipids of human plasma when compared to that of rabbit. Since 22 carbon fatty acids were present in the fats of aquatic origin and in some of the vegetable oils and $\mathrm{C}_{22: 6}$ was found to be high in fish oil, it is not surprising that dog and rat plasma contained very little $\%$ of 22 fatty acids. Besides, these animals were not fed foods which contained appreciable amounts of 22 carbon fatty acids. The previous data revealed that RBC fatty acid composition reflected the type of the fat put in the diet. It was found that fish oil-enriched diet caused significant changes in the fatty acid pattern of serum phospholipids and RBC membrane in rabbits. High amounts of $\mathrm{C}_{20: 5}, \mathrm{C}_{22: 5}$ and $\mathrm{C}_{22: 6}$ were abtained by feeding with fish oil (18). These results were in agreement with previously published results on monkeys (29), rats (7), rabbits (30) and humans (31).

Among MUFAs $\mathrm{C}_{18: 1}$ was found to be higher than that of the other MUFAs, particularly high in all phospholipids of human and rabbit. $\mathrm{Ci}_{6: 0}$ and $\mathrm{Ci}_{8: 0}$ contents were higher than that of other SFAs in the phospholipids. Percentage of fatty acids in the phospholipids generally decreased in the following order: SFA $>$ MUFA $>$ PUFA with little exceptions. PUFA \% was higher in PE and PC and PUFA>MUFA in rabbit and human plasma, whereas PUFA \% was higher in PC and PS in dog and in PI, PC and SPH in rat.

\section{CONCLUSION}

The prominent fatty acids in plasma phospholipids of rat, rabbit, dog and human were Ci6:o, Ci6:i, $\mathrm{C}_{\mathrm{i} 8: 0}, \mathrm{C}_{\text {18:1 }}, \mathrm{C}_{18: 2}$ and $\mathrm{C}_{20} \mathrm{0} .4 . \mathrm{C}_{18: 2}$ and $\mathrm{C}_{20} 4$ were the major PUFAs PC and PE were found to be main fatty acids whereas PS, PI and SPH followed them in all of the species. $\mathrm{C}_{18: 2}$ 
was higher and $\mathrm{C}_{20:} 4$ was lower in rabbit phospholipids when compared to other species. This probably indicates the lower activities of elongase and $\mathrm{A}^{5}$-desaturase synthesizing arachidonate from linoleate in the rabbit. Among the PUFAs, $\mathrm{C}_{20} 5$ was found to be present in human plasma phospholipids while among the LCPUFAs, $\mathrm{C}_{2} 2: 6$ was found to be present in some of the phospholipids. LCPUFAs were not present in dog and rat whereas dog had small amouts of $\mathrm{C}_{2} 2: 4$ in PC indicating that elongase and $A^{5}$-desaturase enzymes capable of synthesizing $\mathrm{C}_{22} 6$ were lower in dog and rat. It was concluded that this might be due to the present diet. The enzymes synthesizing LCPUFA in dog and rat could be analyzed in the further studies and could be compared.

\section{REFERENCES}

1. Synder, F. Lee, T.C. and Blank, M.L. The role of transacylases in the metabolism of arachidonate and platelet activating factor. Prog. Lipid Res. 31, 65-86 (1992).

2. Sugiura, T. and Waku, K. Coenzyme A-independent acyltransferase. Methods Enzymol. 209,72-80(1992).

3. Kinsella, J.E. Lipids, membrane receptors and enzymes:effect of dietary fatty acidsJPEN 74(Suppl 2), 200S-18S (1990).

4. Spector, A.A. and Yorek, M.A. Membrane lipid composition and cellular function. J.Lipid Res. 26, 1015-35(1985).

5. Lewis, R. A. and Austen K.F. The biologically active leukotrienes. Biosynthesis, metabolism, reseptors, functions and pharmacology. J. Clin. Invest. 73, 889-97 (1984).

6. Hartl W. H. and Wolfe, R. R. The phospholipid / arachidonic acid second messenger system: its possible role in physiology and pathophysiology of methabolism. JPEN. 14, 416-227(1990).

7. Rao, C.V., Zang, E. and Reddy, B.S. Effect of high fat corn oil, olive oil and fish oil on phospholipid fatty acid composition in male F344 rats. Lipids 28, 441-447 (1993).

8. Folsom, A.R., Ma, J., Eckfeldt, J.H., Shahar, E. and Wu, K.K. Plasma phospholipid fatty acid composition and factor VII coagulant activity. Atherosclerosis III, 199-207 (1994).

9. Giron, M.D., Mataix, F.J., and Suarez, M.D. Long-term effects of dietary monounsaturated and polyunsaturated fatty acids on the lipid composition of erythrocyte membranes in dogs. Comp. Biochem. Physiol. 1002 A (1), 197-201 (1992). 
10. Ghosal, J. Biswas T., Ghosh, A. and Datta, A.G. Effect of erythropoietin on the lipid composition of red blood cell membrane. Biochem. Med. 32, 1-14 (1984).

11. Nelson, G.J., Schmidt, P.C., Bartolini, G.L., Kelley, D.S. and Kyle, D. The effect of dietary docosahexaenoic acid on plasma lipoproteins and tissue fatty acid composition in humans. Lipids 32, 1137-1146 (1997).

12. Narasimhamurty, K. and Raina, P.L. Long term feeding effects of heated and fried oils on lipids and lipoproteins in rats. Mol. Cell. Biochem. 195, 143-153 (1999).

13. Pita, M-L. and Delgado, M-J. Folate administration increases n-3 polyunsaturated fatty acids in rat plasma and tissue lipids. Thromb. Haemost. 84, 420-423 (2000).

14. Cleland, L. G., Neumann, M.A., Gibson, R.A., Hamazaki, T., Akimoto, K. and James, M.J. Effect of dietary n-9 eicosatrienoic acid on the fatty acid composition of plasma lipid fractions and tissue phospholipids. Lipids 31, 829-837 (1996).

15. Tichelaar, H.Y., Smuts, CM., Gross, R., Jooste, P.L. Faber, M. and Benade, A.J.S. The effect of dietary iron deficiency on the fatty acid composition of plasma and erythrocyte membrane phospholipids in the rat. Prostaglandins Leukotrienes and Essential Fatty Acids. 56,229-233(1997).

16. Hoffman, D.R., Uauy, R. and Birch, D.G. Red blood cell fatty acid levels in patients with otosomal dominant retinitis pigmentosa. Exp. Eye Res 57, 359-368 (1993).

17. Hodge, J., Sanders, K. and Sinclair, A.J. Differential utilisation of eicosapentaenoic acid and docosahexaenoic acid in human plasma. Lipids 28, 525-531 (1993).

18. van den Boom, M.A.P., Groot wassink M., Roelefsen, B., de Fouw NJ. and Op den Kamp, j.A.F. The influence of a fish oil-enriched diet on the phospholipid fatty acid turnover in the rabbit red cell membrane in vivo. Lipids 31, 285-293 (1996).

19. van deen Boom, M.A.P. Groot Wassink M., Westerman, J., de Fouw N.J., Roelofsen, B., op den Kamp, J.A.F. and van Deenen L.L.M. In vivo turnover of phospholipids in rabbit erythrocytes. Biochim. Biophys. Acta 1215, 314-320 (1994).

20. Boyle, F. G., Yuhas, R. J. and Lien, E. L. Red blood cell and tissue phospholipid fatty acid profiles of weanling rats fed infant formula fat blends containing soy and/or corn oil. Ann. Nutr. Metab. 40. 234-242 (1996). 
21. Nordoy, A., Davenas, E., Ciavatti, M. and Renaud, S. Effect of dietary (n-3) fatty acids on platelet function and lipid metabolism in rats. Biochim. Biophys. Acta 835, 491-500 (1985).

22. Parsons, H. G., Hill, R., pencharz, P. and Kuksis, A. Modulation of human erytrocyte shape and fatty acids by diet. Biochim. Biophys. Acta. 860, 420-427 (1986).

23. Lepage, G., Levy, E., Ronco, N., Smith, L., Galeano, N. and Roy, C. C. Direct transesterification of plasma fatty acids for the diagnosis of essential fatty acid deficiency in cystic fibrosis. J. Lip. Res. 30, 1483-1490 (1989).

24. Verdon, C.P. and Blumberg, J.B. An assay for the a-tocopherol binding protein mediated transfer of vitamin E between membranes. Anal. Biochem. 169, 109-120 (1988).

25. Pekiner, B. and Pennock, J.F. Oxidation of human red blood cells by a free radical initiator and effects of radical scavengers. Biochem. Mol. Biol. Int. 33, 1159-1167 (1994).

26. Skipsky, V.P. and Barclay, M. Thin layer chromatography of lipids. Methods Enzymol. 14,530-598(1969).

27. Christie, W.W. in High Performance Liquid Chromatography and Lipids, Pergamon Press, Oxford, 133 (1987).

28. Mangold, H.K. in Thin Layer Chromatography (Stahl, E. Ed.), Springer-Verlag, New York, 363 (1969).

29. Carman, M.A. and Beare-Rogers, J.L. Influence of diet on (n-3) and (n-6) fatty acids in monkey erythrocytes. Lipids 23, 501-503 (1988).

30. Van den berg, J. J. M., de Fouw, N. J., Kuypers F. A., Roelofsen B., Houtsmuller, U. M. T. and Op den Kamp, J. A. F. Increased (n-3) polyunsaturated fatty acid content of red blood cells from fish oil-fed rabbits increases lipid peroxidation, but decreases haemolysis. Free Rad. Biol. Med. 11, 393-399 (1991).

31. Brown, A.J., Pang, E. and Roberts, D.C.K. Erythrocyte eicosapentaenoic acid as a marker for fish and fish oil consumption. Am. J. Clin. Nutr. 54, 668-673 (1991).

Received: 29.04 .2003

Accepted: 09.06.2003 